\title{
CEO Compensation in Canada, 1971-2008
}

\author{
Patrice Gélinas $^{1} \&$ Lisa Baillargeon ${ }^{2}$ \\ ${ }^{1}$ School of Administrative Studies, York University, Toronto, Canada \\ ${ }^{2}$ École des Sciences de la Gestion, Université du Québec à Montréal, Montréal, Canada \\ Correspondence: Patrice Gélinas, School of Administrative Studies, Faculty of Liberal Arts \& Professional \\ Studies, York University, Toronto, Canada. Tel: 1-416-736-2100 ext. 20082. E-mail: gelinas@yorku.ca
}

Received: March 11, 2013 Accepted: March 27, 2013 Online Published: May 14, 2013

doi:10.5539/ijbm.v8n12p1 URL: http://dx.doi.org/10.5539/ijbm.v8n12p1

\begin{abstract}
This paper draws from a unique database spanning over 35 years of Canadian CEOs' compensation to explore the interplay among: the information available to boards of directors of Canadian companies for making executive pay decisions, the Canadian business environment, and the compensation that Canadian CEOs received. We find a very strong correlation between Canadian CEOs' compensation and the amount of information on CEO compensation available to boards of directors. We further note that the evolution of the Canadian business environment has shaped the information produced and made available to boards of directors regarding CEO compensation.
\end{abstract}

Keywords: executive compensation, corporate governance, Canada, longitudinal study, business history

\section{Introduction}

Over the last four decades, the Canadian executive compensation landscape has changed radically through successions of transformational leaps and progressive evolutionary periods. While in 1971 boards of directors had only a few statistics on executive compensation available to elaborate executive compensation programs and strategies, their informational environment became more and more complex over time. For the CEO position alone, for instance, over 1,400 statistics were available from the published report of a single consultancy in 2008. Yet, a comprehensive longitudinal review of the CEO compensation phenomenon in a Canadian setting remains inexistent despite relatively abundant literature on CEO pay produced in academia and by the press.

This can be explained. Firstly, most academics studying executive compensation are trapped in management capture and market forces theories to explain the levels of executive compensation (Elson and Ferrere, 2012) and in the dominant agency theory paradigm (Jensen and Meckling, 1976) to explain the structure of executive compensation. These approaches are more contusive to the exploration of punctual events and pay-performance relationships and to the disregard for business environment changes that occur gradually or that may be better appreciated over long time. Secondly, the press has always covered executive compensation with a sensationalist appetite for anecdotal excesses that readers are led interpret as unethical. Thirdly, public disclosure of Canadian CEOs' compensation is only available publicly since 1994 following changes in Canadian disclosure regulation in 1993. By comparison, executive compensation is disclosed in the U.S. since the late 1930s, which has enabled researchers to study U.S. executive compensation for periods beginning after the Second World War (see Frydman \& Jenter, 2010; Frydman \& Saks, 2010; Murphy, 1999).

Since the 1980s', a global explosion occurred in executive compensation analysis with research growing to an interdisciplinary literature bridging accounting, economics, finance, industrial relations, law, organizational behavior and strategy (Murphy 1999). Before that time, just a few studies on executive compensation had been published. Among them are pioneer studies from Roberts (1956), Baumol (1959) and Lewellen and Huntsman (1970) which were focusing mainly on ties between pay and company size or company profits which have been proved to be relatively uninteresting and totally lost in multicollinearity problems (Ciscel \& Carroll, 1980; Rosen, 1992; Murphy, 1999).

The modern history of executive compensation began in parallel with the emergence and acceptance of agency theory (Jensen and Meckling 1976; Mirrlees, 1974 and 1976; Ross, 1973; Holmstrom 1979 and 1982; Fama, 1980; Lazear \& Rosen 1981; Grossman \& Hart, 1983). "The separation of ownership and control in corporations is, after all, the quintessential agency problem suggested by Berle and Means (1932) and formalized by Jensen 
and Meckling (1976), and the executive labor market is a natural laboratory for testing its implications" (Murphy, 1999, 2). Not surprisingly, the structuration of executive compensation as a strategic governance activity led to the emergence of professional executive compensation consulting and to the production of independent surveys of executive compensation to help boards of directors solve the agency problem to the best of their capacity.

Research in Canadian contexts has joined the U.S. where it was at, as soon as researchers gained access to public disclosures on Canadian executive compensation. In other words, over the last two decades, the literature on Canadian executive compensation has focused on agency-related issues through event studies and multi-country comparisons (e.g., Craighead et al., 2004; Gélinas et al., 2009; Magnan et al., 1996; Zhou 1999 and 2003). The inability of agency theory and other theories explaining compensation to explain executive compensation comprehensively and satisfactorily has led to the development of rival theoretical lenses, but none of them has so far been able to explain executive compensation completely and more exploratory research and theoretical development is being called for (Frydman \& Jenter, 2010).

In this paper we provide an explorative historical account of the evolution of executive compensation in Canada between 1971 and 2008. More specifically we explore the interplay among (1) the information available to board of directors of Canadian companies for making executive pay decisions, (2) the Canadian business environment, as well as (3) the compensation that Canadian CEOs received. Our objective is to inform researchers and theorists of a variable that could help to explain executive compensation and that has been ignored in the literature: the quantity of information on executive pay available to boards of directors.

It is well known that the information made available to boards of directors regarding executive compensation may have unintended consequences (Matsumura \& Shin, 2005), such as leading to undue executive compensation increases. Such observations are consistent with the managerial power (Bebchuk et al., 2002) and competitive market forces arguments found in the literature (see Frydman \& Jenter, 2010). More market data provides powerful CEOs with a stronger bargaining arsenal to increase their own pay by focusing on elements where they stand comparatively low relative to peers and by ignoring elements where the company is comparatively high. Such a behavior has an upward ratcheting an effect on general pay levels. Consequently, we explore in this paper the following intuitive proposition:

P1. CEO compensation increases as the amount of information available to boards of directors regarding CEO compensation increases.

The powerful manager view of executive compensation (also known as optimal contracting, management capture or rent extraction) would further suggest that when managers have the upper hand in negotiating their pay and that each piece of information on peer CEOs' compensation may be used as evidence to increase their own compensation, then the demand for market CEO compensation information, which may originate from the CEOs themselves, should grow constantly. Hence we propose:

P2. The amount of information produced on CEO compensation grows over time.

\section{Methodology}

We started our explorative research with an inquisitive glance at the evolution of the executive compensation surveys in Canada over the years. This has enabled us to observe that compensation increases over time, but also notably that compensation increases with the amount of information that boards of directors have available to elaborate compensation programs. Following the development of our research hypotheses, we devised to gather formal statistical evidence.

The analyses rely on market data published in the annual Canadian executive compensation survey of a large and reputable consultancy company from 1971 to 2008. This source of data is unique and unavailable to the public. The consultancy no longer exists as a result of industry consolidation and corporate transactions. We recorded from historical paper-based survey publications a database totalling over 14,500 statistics on compensation for the CEO position. For each year, we recorded all available data on compensation components, such as salary, short- and long-term incentives, pension, benefits and perquisites as well as on position scope such as geographic responsibility, management level, board membership, company revenues/size, and number of employees. Some of the statistics were derived from yearly regression analyses of the relationship between pay and company scope that the consultancy made available to its clients. Data were summarized in two tables. Table 1 presents the evolution in median total CEO compensation based on regression analysis projections for a company scope corresponding to annual revenues of CAD $\$ 800$ million, along with the number of statistics on CEO compensation available to boards of directors in the annual survey. Providing compensation information specific to a single and fixed company scope enables us to control for this variable which is widely documented for being 
linked to CEO pay levels (e.g., see Ciscel and Carroll, 1980). Importantly, total compensation data represent the most comprehensive definition of total compensation made available to the survey participants each year. The emergence and then prominence of long-term incentives in Canada has made the most comprehensive definition of total compensation evolve from total cash (salary + annual bonus) to total direct compensation (salary + annual bonus + value of long-term incentives) starting with the year 2000 report.

Table 1. Canadian CEO compensation at firms with annual revenues of $\$ 800$ million (in Canadian dollars)

\begin{tabular}{|c|c|c|c|c|c|c|c|}
\hline \multirow[t]{2}{*}{ Year } & \multirow[t]{2}{*}{ \# of Participants } & \multicolumn{2}{|c|}{ Salary } & \multicolumn{3}{|c|}{ Total Compensation* } & \multirow[t]{2}{*}{ \# Stats Available } \\
\hline & & Amount (\$) & Increase & Amount (\$) & Increase & Form & \\
\hline 1971 & 33 & & & 142,667 & & $\mathrm{TC}$ & 49 \\
\hline 1972 & 48 & & & 120,667 & $-18 \%$ & TC & 49 \\
\hline 1973 & 40 & & & 146,200 & 17 & $\mathrm{TC}$ & 56 \\
\hline 1974 & 61 & & & 173,282 & 16 & $\mathrm{TC}$ & 63 \\
\hline 1975 & 101 & 139,691 & & 140,563 & -23 & $\mathrm{TC}$ & 74 \\
\hline 1976 & 119 & 133,713 & $-4 \%$ & 139,939 & 0 & $\mathrm{TC}$ & 74 \\
\hline 1977 & 119 & 113,671 & -18 & 136,553 & -2 & $\mathrm{TC}$ & 74 \\
\hline 1978 & 122 & 167,543 & 32 & 133,334 & -2 & $\mathrm{TC}$ & 74 \\
\hline 1979 & 141 & 146,471 & -14 & 145,828 & 9 & $\mathrm{TC}$ & 74 \\
\hline 1980 & 141 & 162,164 & 10 & 201,525 & 28 & $\mathrm{TC}$ & 86 \\
\hline 1981 & 146 & 179,992 & 10 & 219,066 & 8 & $\mathrm{TC}$ & 86 \\
\hline 1982 & 171 & 193,682 & 7 & 225,754 & 3 & $\mathrm{TC}$ & 86 \\
\hline 1983 & 177 & 198,830 & 3 & 221,357 & -2 & $\mathrm{TC}$ & 86 \\
\hline 1984 & 208 & 211,003 & 6 & 241,831 & 8 & $\mathrm{TC}$ & 86 \\
\hline 1985 & 280 & 215,999 & 2 & 256,218 & 6 & $\mathrm{TC}$ & 119 \\
\hline 1986 & 280 & 243,762 & 11 & 271,965 & 6 & $\mathrm{TC}$ & 99 \\
\hline 1987 & 335 & 243,762 & 0 & 293,829 & 7 & $\mathrm{TC}$ & 99 \\
\hline 1988 & 332 & 264,770 & 8 & 314,374 & 7 & $\mathrm{TC}$ & 103 \\
\hline 1989 & 363 & 252,068 & -5 & 324,482 & 3 & $\mathrm{TC}$ & 139 \\
\hline 1990 & 373 & 268,495 & 6 & 335,062 & 3 & $\mathrm{TC}$ & 182 \\
\hline 1991 & 368 & 275,936 & 3 & 325,957 & -3 & $\mathrm{TC}$ & 182 \\
\hline 1992 & 317 & 282,426 & 2 & 334,295 & 2 & $\mathrm{TC}$ & 179 \\
\hline 1993 & 301 & 289,069 & 2 & 342,564 & 2 & $\mathrm{TC}$ & 179 \\
\hline 1994 & 267 & 302,579 & 4 & 376,171 & 9 & $\mathrm{TC}$ & 179 \\
\hline 1995 & 262 & 310,778 & 3 & 410,048 & 8 & $\mathrm{TC}$ & 179 \\
\hline 1996 & 92 & 374,747 & 17 & 503,858 & 19 & $\mathrm{TC}$ & 382 \\
\hline 1997 & 87 & 385,571 & 3 & 541,651 & 7 & $\mathrm{TC}$ & 392 \\
\hline 1998 & 72 & 422,170 & 9 & 622,585 & 13 & $\mathrm{TC}$ & 392 \\
\hline 1999 & 84 & 410,883 & -3 & 606,120 & -3 & $\mathrm{TC}$ & 392 \\
\hline 2000 & 114 & 416,632 & 1 & 947,429 & 36 & $\mathrm{TD}$ & 560 \\
\hline 2001 & 111 & 457,015 & 9 & $1,026,350$ & 8 & TD & 1,009 \\
\hline 2002 & 138 & 469,416 & 3 & $1,181,063$ & 13 & TD & 1,009 \\
\hline 2003 & 156 & 501,654 & 6 & $1,287,535$ & 8 & TD & 1,087 \\
\hline 2004 & 133 & 514,451 & 2 & $1,422,873$ & 10 & TD & 1,111 \\
\hline 2005 & 130 & 542,146 & 5 & $1,355,720$ & -5 & $\mathrm{TD}$ & 1,111 \\
\hline 2006 & 127 & 540,514 & 0 & $1,508,874$ & 10 & TD & 1,111 \\
\hline 2007 & 120 & 574,782 & 6 & $1,628,304$ & 7 & TD & 1,867 \\
\hline 2008 & 101 & 583,000 & 1 & $1,727,488$ & 6 & TD & 1,435 \\
\hline
\end{tabular}

* From 1971 to 1974 total compensation includes Base Salary and Annual Bonuses

$*$ TC: Total Cash Compensation $=$ Base Salary + Annual Bonuses

*TD: Total Direct Compensation $=\mathrm{TC}+$ Value of Long-term Incentives

Correlation Coefficient (Salary, Number of Statistics): $90.8 \%$

Correlation Coefficient (Total Compensation, Number of Statistics): $97.6 \%$

Source: Market data from the annual Canadian executive compensation survey, 1971-2008. 
Table 2 presents the evolution of the number and types of statistics on CEO compensation available to Canadian boards of directors over time. From a mere 49 statistics on Canadian CEO compensation in 1971, the survey has peaked to over 38 times as many in 2007 with 1,867 statistics available for the CEO position alone while the number of CEO cases in the survey (or participants reporting a CEO position) had less than quadrupled from 33 to 120 over the same period.

Table 2. Change in the number of statistics on CEO compensation in a Canadian consultancy's annual survey

\begin{tabular}{|c|c|c|c|c|c|c|c|}
\hline Year & $\begin{array}{c}\text { \# of } \\
\text { Participants }\end{array}$ & $\begin{array}{c}\text { Scope } \\
\text { Information }\end{array}$ & $\begin{array}{c}\text { Fixed } \\
\text { Compensation }\end{array}$ & $\begin{array}{c}\text { Variable } \\
\text { Compensation }\end{array}$ & $\begin{array}{c}\text { Fixed and Variable } \\
\text { Compensation }\end{array}$ & $\begin{array}{c}\text { Total } \\
\text { Change }\end{array}$ & $\begin{array}{l}\text { Total \# of } \\
\text { Statistics }\end{array}$ \\
\hline 1971 & 33 & 0 & +37 & 0 & +12 & +49 & 49 \\
\hline 1972 & 48 & 0 & 0 & 0 & 0 & 0 & 49 \\
\hline 1973 & 40 & +4 & +3 & 0 & 0 & +7 & 56 \\
\hline 1974 & 61 & 0 & +3 & +4 & 0 & +7 & 63 \\
\hline 1975 & 101 & +8 & +2 & -4 & +5 & +11 & 74 \\
\hline 1976 & 119 & 0 & 0 & 0 & 0 & 0 & 74 \\
\hline 1977 & 119 & 0 & 0 & 0 & 0 & 0 & 74 \\
\hline 1978 & 122 & 0 & 0 & 0 & 0 & 0 & 74 \\
\hline 1979 & 141 & 0 & 0 & 0 & 0 & 0 & 74 \\
\hline 1980 & 141 & 0 & +6 & 0 & +6 & +12 & 86 \\
\hline 1981 & 146 & 0 & -1 & 0 & +1 & 0 & 86 \\
\hline 1982 & 171 & 0 & 0 & 0 & 0 & 0 & 86 \\
\hline 1983 & 177 & 0 & 0 & 0 & 0 & 0 & 86 \\
\hline 1984 & 208 & 0 & 0 & 0 & 0 & 0 & 86 \\
\hline 1985 & 280 & 0 & +25 & +16 & -8 & +33 & 119 \\
\hline 1986 & 280 & 0 & -16 & -4 & 0 & -20 & 99 \\
\hline 1987 & 335 & 0 & 0 & 0 & 0 & 0 & 99 \\
\hline 1988 & 332 & 0 & 4 & 0 & 0 & +4 & 103 \\
\hline 1989 & 363 & 0 & 0 & +36 & 0 & +36 & 139 \\
\hline 1990 & 373 & +4 & +39 & 0 & 0 & +43 & 182 \\
\hline 1991 & 368 & 0 & 0 & 0 & 0 & 0 & 182 \\
\hline 1992 & 317 & 0 & -2 & 0 & -1 & -3 & 179 \\
\hline 1993 & 301 & 0 & 0 & 0 & 0 & 0 & 179 \\
\hline 1994 & 267 & 0 & 0 & 0 & 0 & 0 & 179 \\
\hline 1995 & 262 & 0 & 0 & 0 & 0 & 0 & 179 \\
\hline 1996 & 92 & +88 & +33 & -4 & +32 & +149 & 328 \\
\hline 1997 & 87 & 0 & +61 & 0 & +3 & +64 & 392 \\
\hline 1998 & 72 & 0 & 0 & 0 & 0 & 0 & 392 \\
\hline 1999 & 84 & 0 & 0 & 0 & 0 & 0 & 392 \\
\hline 2000 & 114 & +40 & +8 & +80 & +40 & +168 & 560 \\
\hline 2001 & 111 & +72 & +320 & +20 & +37 & +449 & 1,009 \\
\hline 2002 & 138 & 0 & 0 & 0 & 0 & 0 & 1,009 \\
\hline 2003 & 156 & +72 & +6 & 0 & 0 & +78 & 1,087 \\
\hline 2004 & 133 & -30 & +54 & 0 & 0 & +24 & 1,111 \\
\hline 2005 & 130 & 0 & 0 & 0 & 0 & 0 & 1,111 \\
\hline 2006 & 127 & 0 & 0 & 0 & 0 & 0 & 1,111 \\
\hline 2007 & 120 & +54 & +630 & +72 & 0 & +756 & 1,867 \\
\hline \multirow[t]{2}{*}{2008} & 101 & 0 & -486 & +54 & 0 & -432 & 1,435 \\
\hline & & 312 & 726 & 270 & 127 & 1,435 & \\
\hline
\end{tabular}

Source: Market data from the annual Canadian executive compensation survey, 1971-2008. 


\section{Findings}

Findings presented in Table 1 and in Table 2 are consistent with both P1 and P2, but more research will be required to demonstrate the causality of the observed relationships and to refine theoretical justifications. Table 1 shows that median Canadian CEO compensation and the number of statistics on CEO compensation available in the survey over the 1971-2008 period have evolved jointly. Indeed, the positive correlation between nominal median total compensation and the number of statistics available to boards is impressive at over $97 \%$. Correlation remains high at over $94 \%$ when calculated using real (inflation-adjusted) total compensation instead of nominal. Meanwhile correlation between nominal median annual salary and the number of statistics is positive and at over $90 \%$. It is over $80 \%$ when calculated using real salary. These findings are consistent with $\mathrm{P} 1$ because they suggest that Canadian CEOs' compensation is positively linked to the quantity of information on compensation available to boards of directors when they determine CEO pay.

Following 1993, when mandatory disclosure of CEO compensation was implemented by the Canadian Securities Administrators, compensation started to increase at a greater pace. This finding is consistent with a trend already observed by Craighead et al. (2004) in the Canadian context. For example, median salaries in Table 1 increased at an average pace of $4.1 \%$ between 1975 and 1993 while the average increases were $4.8 \%$ between 1994 and 2008. Meanwhile, the annual average inflation rate (Consumer Price Index change) averaged $6.2 \%$ over the 1975-1993 period while it averaged 1.9\% over the 1994-2008 period. The average real (inflation-adjusted) salary increase was consequently negative at $-2.1 \%$ pre-disclosure while it was positive at $2.9 \%$ after disclosure. Total compensation figures are consistent but the pre- vs. post-disclosure spread is greater (5.4\% vs. $11.4 \%)$. This confirms, as agency theory would predict, that boards have since at least 1975 placed an increasing emphasis on variable compensation within the total CEO compensation envelop. However these results are more challenging to interpret because the definition of total compensation has changed over the period.

Indeed, Table 1 shows that the definition of total compensation that boards of directors had to determine CEO compensation has started to include long-term incentives in 2000, when the most comprehensive definition of total compensation changed from total cash (salary + annual bonus) to total direct compensation (salary + annual bonus + long-term incentives). This coincides with the pinnacle of the dotcom bubble where many companies from the so-called "new economy" started to provide long-term incentives to a broad population of employees, essentially through stock option plans (Oyer \& Schaefer, 2005; Sesil et al., 2002). This has certainly forced boards of companies from the "old economy" to consider long-term incentives more consistently for competitive purposes, hence the rigorous apparition of long-term incentive data in the survey and the soaring number of compensation statistics. Real salary increases between 1975 and 2000 (i.e. pre-dotcom bubble) were slightly negative at $-0.4 \%$ while real salary increases averaged $1.3 \%$ between 2001 and 2008 . By contrast, real total cash compensation increases averaged $2.9 \%$ over the $1975-2000$ period while real total direct compensation increased by an average of 5.5\% per year between 2001 and 2008. Also consistent with agency theory arguments, these findings reconfirm that most of the CEO pay increases came from variable (or at-risk) pay over the whole studied period. Consistent with P1, real increases appear to have been catalysed by the emergence of more abundant and comprehensive information on incentives in surveys because the number of statistics on CEO compensation more than doubled from 1999 to 2001, the zenith of the dotcom frenzy (392 vs. 1,009 statistics).

A significant increase in CEO compensation is also observable from 1995 to 1996 because the definition of CEO has changed in the database methodology to include only CEOs of autonomous companies and no longer include CEOs of subsidiary companies, which are numerous in Canada. This also explains why the number of cases dropped significantly over this single year as the survey started to include the new position of "Subsidiary CEO" and to report this new position benchmark's own statistics separately. This change is consistent with P2 since it has multiplied the angles from which CEO compensation can be assessed.

Table 2 also shows a steady, if not an exponential progression by leaps, in the number of company scope statistics available over time. This suggests that boards devoted ever increasing and more granular attention to the characteristics of the peers found in the comparator group used to benchmark and determine CEO compensation. Relentless additions of scope statistics in the survey over time are also consistent with P2.

Finally, the ever increasing number of statistics on fixed and variable compensation that were presented in the survey is also consistent with P2. Year 2000 seems to mark a significant push towards a more comprehensive definition of total compensation with the addition of numerous statistics on long-term incentives as well as pension, benefits and perquisites. The dotcom event appears to have had a significant effect on CEO compensation by raising the awareness on pay that can be realized through long-term incentives and through indirect compensation such as pension, benefits and perquisites or even learning opportunities (see Slade et al., 
2002).

\section{Conclusion}

This research is the first to explore the link between CEO compensation and the quantity of information considered by the board of directors in the elaboration of CEO compensation packages. It is also the first paper to analyse Canadian CEOs' compensation over such an extended period of time. This exploratory paper is important because Frydman and Jentner (2010)'s comprehensive longitudinal study of executive compensation led them to conclude that more explorative and theoretical research on executive compensation is required to fully understand, with theories that will pass the test of time, the much researched phenomenon that is executive compensation.

The most important finding of this paper is that we document a strong link between CEO compensation and the amount of information that is available to board of directors. While this finding can be intuitively connected to managerial power, to market for talent and to agency explanations of executive compensation, it could also open the path to new and important avenues of research in executive compensation rooted in decision or information theories.

This paper has limitations. First, it documents correlations, not causalities. The managerial power argument used to justify P1 and P2 is intuitive and compelling, but more research would need to be done to confirm that the amount of information on CEO compensation leads to CEO compensation increases, and not the other way around. It could be plausible to assert that as CEO compensation increases, boards become increasingly meticulous in how they determine CEO pay, and thus command more granular information over time. Second, we have analyzed a limited number of business environment changes. Even though conclusions appear similarly supportive of our propositions from one to the next, more environmental changes could be investigated and simultaneous events could be filtered out more decisively. Third, our analyses are admittedly crude for this exploration. More research could be done to identify moderating variables as well as to conclude regarding causality. Finally, the data set used for this study is just one of several existing sources of Canadian CEO compensation information. Other sources exist, notably the public disclosures as well as surveys prepared by rival consultancies and their analysis could add robustness to the findings.

\section{References}

Baker, G., \& Hall, B. (2004). CEO Incentives and Firm Size. Journal of Labor Economics, 22(2), 767-798. http://dx.doi.org/10.1086/423154

Baumol, W. (1959). Business Behavior, Value and Growth. New York.

Bebchuk, L. A., Fried, J. M., \& Walker, D. I. (2002). Managerial Power and Rent Extraction in the Design of Executive Compensation. The University of Chicago Law Review, 69(3), 751-846. http://dx.doi.org/10.2307/1600632

Berle, A. A., \& Means, G. C. (1932). The Modern Corporation and Private Property. New York.

Ciscel, D., \& Carroll, T. (1980). The Determinants of Executive Salaries: An Econometric Survey. Review of Economics and Statistics, 62(1), 7-13. http://dx.doi.org/10.2307/1924267

Craighead, J., Magnan, M. L., \& Thorne, L. (2004). The Impact of Mandated Disclosure on Performance-Based CEO Compensation. Contemporary Accounting Research, 21(2), 369-398. http://dx.doi.org/10.1506/BPCX-D3FC-Y8VY-M541

Elson, C. M., \& Ferrere, C. K. (2012). Executive Superstars, Peer Groups and Over-Compensation-Cause, Effect and Solution. Peer Groups and Over-Compensation-Cause, Effect and Solution (August 7, 2012).

Fama, E. (1980). Agency Problems and the Theory of the Firm. Journal of Political Economy, 88(2), 288-307. http://dx.doi.org/10.1086/260866

Frydman, C., \& Jenter, D. (2010). CEO Compensation. Annual Review of Financial Economics, 2(1), 75-102. http://dx.doi.org/10.1146/annurev-financial-120209-133958

Frydman, C., \& Saks, R. E. (2010). Executive Compensation: A New View from a Long-Term Perspective, 1936-2005. Review of Financial Studies, 23, 2099-2138. http://dx.doi.org/10.1093/rfs/hhp120

Gélinas, P., Magnan, M. L., \& St-Onge, S. (2009). Increased compensation costs as an externality of mandatory executive compensation disclosure: Evidence from Canada. International Journal of Business Environment, 2(3), 376-390. http://dx.doi.org/10.1093/10.1504/IJBE.2009.023797

Grossman, S., \& Hart, O. (1983). An Analysis of the Principal-Agent Problem. Econometrica, 51, 7-45. 
http://dx.doi.org/10.2307/1912246

Holmstrom, B. (1979). Moral Hazard and Observability. The Bell Journal of Economics, 10, 74-91. Retrieved from http://www.jstor.org/stable/3003320

Holmstrom, B. (1982). Moral Hazard in Teams. The Bell Journal of Economics, 13(2), 324-40. Retrieved from http://www.jstor.org/stable/3003457

Jensen, M. C., \& Murphy, K. J. (1990). Performance Pay and Top-Management Incentives. Journal of Political Economy, 98, 225-264. http://dx.doi.org/10.1086/261677

Jensen, M., \& Meckling, W. (1976). Theory of the Firm: Managerial Behavior, Agency Costs and Ownership Structure. Journal of Financial Economics, 3, 305-360. http://dx.doi.org/10.1016/0304-405X(76)90026-X

Jensen, M., \& Murphy, K. J. (1990b). CEO Incentives: It's Not How Much, but How. Harvard Business Review, May/June, 64-76.

Lazear, E., \& Rosen, S. (1981). Rank-Order Tournaments as Optimum Labor Contracts. Journal of Political Economy, 89, 841-864. Retrieved from http://www.jstor.org/stable/1830810

Lewellen, W., \& Huntsman, B. (1970). Managerial Pay and Corporate Performance. American Economic Review, 60, 710-720. Retrieved from http://www.jstor.org/stable/1818414

Magnan, M. L., St-Onge, S., \& Thorne, L. (1996). Performance organisationnelle et rémunération des dirigeants: une comparaison Canada- Etats-Unis. Canadian Journal of Administrative Sciences, 13, 102-118. http://dx.doi.org/10.1111/j.1936-4490.1996.tb00108.x

Matsumura, E. M., \& Shin, J. Y. (2005). Corporate governance reform and CEO compensation: Intended and unintended consequences. Journal of Business Ethics, 62(2), 101-113. http://dx.doi.org/10.1007/s10551-005-0175-7

Mirrlees, J. (1974). Notes on Welfare Economics, Information, and Uncertainty. In Balch, M., McFadden, D., \& Wu, S. (Eds.), Essays on Economic Behavior Under Uncertainty (pp. 243-258). North Holland, Amsterdam.

Mirrlees, J. (1976). The Optimal Structure of Incentives and Authority within an Organization. Bell Journal of Economics, 7, 105-131. Retrieved from http://www.jstor.org/stable/3003192

Murphy, K. J. (1999). Executive Compensation. In Ashenfelter, O., \& Card, D. (Eds.), Handbook of Labor Economics $3 B \quad$ (pp. 2485 - 2563). Amsterdam, New York: North Holland. http://dx.doi.org/10.1016/S1573-4463(99)30024-9

Oyer, P., \& Schaefer, S. (2005). Why do some firms give stock options to all employees?: An empirical examination of alternative theories. Journal of Financial Economics, 76(1), 99-133. http://dx.doi.org/10.1016/j.jfineco.2004.03.004

Roberts, D. (1956). A General Theory of Executive Compensation Based on Statistically Tested Propositions. Quarterly Journal of Economics, 70, 270-294. http://dx.doi.org/10.2307/1884268

Rosen, S. (1992). Contracts and the Market for Executives. In Wein, L., \& Wijkander, H. (Eds.), Contract Economics (pp. 181-211). Blackwell Publishers.

Sesil, J. C., Kroumova, M. K., Blasi, J. R., \& Kruse, D. L. (2002). Broad-based Employee Stock Options in US 'New Economy' Firms. British Journal of Industrial Relations, 40, 273-294. http://dx.doi.org/10.1111/1467-8543.00232

Slade, L. A., Davenport, T. O., Roberts, D. R., \& Shah, S. (2002). How Microsoft optimized its investment in people after the dot-com era. Journal of Organizational Excellence, 22(1), 43-52. http://dx.doi.org/10.1002/npr.10052

Zhou, X. (1999). Executive compensation and managerial incentives: A comparison between Canada and the United States. Journal of Corporate Finance, 5, 277-301. http://dx.doi.org/10.1016/S0929-1199(99)00008-5

Zhou, X. (2003). CEO pay, firm size, and corporate performance: Evidence from Canada. Canadian Journal of Economics/Revue canadienne d'économique, 33, 213-251. http://dx.doi.org/10.1111/0008-4085.00013 